\title{
Pengaruh Model Pembelajaran Inkuiri Terbimbing Terhadap Hasil Belajar pada Materi Ikatan Kimia di MAN MODEL 1 Manado
}

\author{
Dhysa Mentari Sulistyaningsih*, Soenandar M. T. Tengker
}

Pendidikan Kimia, FMIPA, Universitas Negeri Manado, Minahasa, Tondano Selatan, 95618, Indonesia

\section{INFO ARTIKEL}

Diterima 26 Juli 2020

Disetujui 30 Desember 2020

\section{Keywords:}

Guided Inquiry

Chemical Bond

Learning Outcomes

Kata kunci:

Inkuiri Terbimbing

Ikatan Kimia

Hasil belajar
A B S T R A C T

\begin{abstract}
This study's purpose is to influence average learning outcomes students who follow learning to use with those who do not use the guided inquiry model. This research was conducted in class X MAN MODEL 1 MANADO odd semester of 2019/2020. This research uses an experimental method by sampling class X mipa 8 as an 9 as a control class. According to t-test from both data collection, it showed value thitung $3,62>t_{\text {tabel }} 2,011$. This $t$-test means that there is a significant influence on chemical bonding material.
\end{abstract}

\begin{abstract}
A BSTRAK
Penelitian ini bertujuan untuk mengetahui Pengaruh model pembelajaran pada hasil belajar siswa, Penelitian ini dilaksanakan di MAN MODEL 1 MANADO pada kelas X semester ganjil tahun ajaran 2019/2020. Penelitian ini menggunakan metode eksperimen dengan pengambilan sampel menggunakan teknik random sampling, diperoleh kelas X MIPA 8 sebagai kelas eksperimen dan kelas X MIPA 9 sebagai kelas kontrol. Pengambilan data menggunakan tes hasil belajar. Hasil penelitian menunjukkan rata-rata hasil belajar kelas eksperimen lebih tinggi dari kelas kontrol. Berdasarkan pada uji-t kedua nilai post-test yaitu dengan thitung 3,62 $>$ tabel 2,011. Dari uji-t berarti ada pengaruh yang signifikan penggunaan model pembelajaran Inkuiri terbimbing terhadap hasil belajar pada materi ikatan kimia.
\end{abstract}

Pemilihan model inkuiri yaitu Inkuiri

\section{Pendahuluan}

Mata pelajaran kimia adalah mata pelajaran yang susah dipahami oleh siswa karena banyaknya konsep yang hanya berupa hafalan- hafalan dan hitungan- hitungan, sehingga keterkaitan konsepnya sangat sulit dipahami oleh siswa [1-5]. Maka dari itu siswa yang mempelajari beberapa materi pada pelajaran kimia perlu dibantu dengan kegiatan praktikum agar mudah dipahami [6-9].

Fungsi laboratorium bukan hanya diartikan sebagai tempat belajar mengajar yang sekedar diajarkan di kelas. Laboratorium kimia bukanlah hanya untuk mempraktekkan apakah cocok dengan teori, tetapi di dalamnya harus mengembangkan proses pembelajaran berfikir dengan timbulnya beberapa pertanyaan $[10,11]$. terbimbing sangat membantu untuk model pembelajaran pada siswa yang menghadapi masalah disaat belajar. Pembelajaran menggunakan model inkuiri terbimbing, guru memfasilitasi dalam suasana belajar didalam kelas [12-16]. Jadi siswa harus aktif dalam mencipatakan pengetahuan, konsep atau gagasan dalam menghadapi masalah didalam kelas yang diberikan oleh guru tersebut.

Pada mata pelajaran kimia hasil belajar siswa SMA MAN MODEL 1 MANADO masih rendah. yaitu rata-rata siswa nilai Kriteria Ketuntasan Minimum (KKM) dengan nilai 75 dari 25 siswa tiap kelas 60 mendapat nilai di bawah KKM. Dalam pembelajaran kimia ada kendala kendala yang dihadapi siswa. 
Beberapa kendala antara lain siswa kesulitan mengerti dan memahami pelajaran kimia untuk materi ikatan kimia, dimana siswa mengalami kesulitan menganalisis sifat-sifat ikatan kimia berdasarkan ikatan nya, siswa tidak bisa secara efektif. Hal ini disebabkan penyampaian pembelajaran yang masih menggunakan metode konvensional, tanpa adanya kegiatan praktikum. Berdasarkan Hasil observasi di sekolah MAN MODEL 1 MANADO, terdiri dari dua kelas pada kelas $X$, dengan jumlah siswa masing-masing 25 orang. Penelitian ini bertujuan untuk mengetahui Pengaruh Model pembelajaran Inkuiri Terbimbing pada materi Ikatan Kimia di Man Model 1 manado. dengan hipotesis yaitu apakah terdapat pengaruh hasil belajar Siswa menggunakan model pembelajaran inkuiri terbimbing.

\section{Metode}

Penelitian ini dilakukan di MAN MODEL 1 MANADO pada bulan Oktober semester ganjil tahun ajaran 2019/2020. Jenis penelitian ini adalah penelitian eksperimen dengan "posttest only control group design" seperti pada gambar 1. Penelitian ini menggunakan model pembelajaran inkuiri terbimbing dengan materi ikatan kimia.

\begin{tabular}{|lll|}
\hline $\mathrm{R}$ & $\mathrm{X}$ & $\mathrm{O}_{2}$ \\
$\mathrm{R}$ & & $\mathrm{O}_{4}$ \\
\hline
\end{tabular}

Gambar 1. posttest only control group design

Keterangan:

$\mathrm{R}=$ Random

$\mathrm{X}=$ kelompok yang diberi perlakuan

$\mathrm{O}_{2}=$ hasil pengukuran kelas eksperimen

$\mathrm{O}_{4}=$ hasil pengukuran kelas kontrol

\section{Hasil dan Pembahasan}

\section{Uji Validitas}

Sebelum penelitian ini dilakukan pengujian validitas dan sesudah diuji terdapat 14 soal yang dinyatakan valid.

Uji Reliabilitas

Pada pengujian reliabilitas data yang didapat yaitu $\mathbf{r}_{11}=0,91$.

\section{Uji Normalitas}

Materi ikatan kimia kriteria nilai Lhitung pada masing-masing kelas lebih kecil dari nilai Ltabel pada taraf signifikan $(\alpha)$

\section{Uji Homogenitas}

Uji homogenitas adalah bagian dari uji syarat sebelum menghitung statistik. Hasil belajar pada uji homogenitas dianalisis kontrol $1,03<$ yaitu 1,98.

\section{Hasil Uji Hipotesis Penelitian}

Tabel 1. Ringkasan Uji t Post-test

\begin{tabular}{lll}
\hline Statistik & $\begin{array}{l}\text { Kelas } \\
\text { Eksperimen }\end{array}$ & $\begin{array}{l}\text { Kelas } \\
\text { Kontrol }\end{array}$ \\
\hline $\begin{array}{l}\text { Jumlah } \\
\text { Responden }\end{array}$ & 25 & 25 \\
$\begin{array}{l}\text { Rata-rata } \\
\text { Selisih }\end{array}$ & 81,92 & 72,96 \\
$\begin{array}{l}\text { Simpangan } \\
\text { Baku }\end{array}$ & 8,82 & 8,69 \\
Varians & 77,91 & \\
t hitung & 3,62 & 75,62 \\
t tabel & 2,010 & \\
\hline
\end{tabular}

Penelititian bertujuan untuk mengetahui seberapa besar Inkuiri Terbimbing siswa di MAN MODEL 1 MANADO. Sebagai kelas kontrol X MIPA 9 diterapkan metode ceramah, pada kelas X MIPA 8 sebagai kelas eksperimen diberikan model pembelajaran yang disertai praktikum dari materi ikatan kimia,. Kelas eksperimen dibagi kemudian membahas topik materi ikatan kimia serta mempresentasikan. Kedua diberikan praktikum dengan percobaan yang berbeda. Kelompok pertama melakukan percobaan mengenai kepolaran beberapa senyawa dengan bahan percobaan margarine, minyak goreng, susu cair dilarutkan dengan aquades untuk mengetahui apakah terjadi endapan atau tidak dan termasuk pada senyawa polar atau non polar. Kelompok kedua melakukan percobaan dengan bahan percobaan detergent cair, gula pasir, dan cuka dilarutkan dengan aquades untuk mengetahui apakah terjadi endapan atau tidak dan termasuk pada senyawa polar atau non polar. Penemuan yang berbeda dari masing-masing kelompok dipresentasikan dan ditanggapi oleh kelompok lain. 
Soal post-test sebelum di uji pada kelas sampel, Soal sebanyak 20 butir di uji pada kelas X MIPA 8 dan dihitung menggunakan rumus uji validitas dikatakan valid apabila rhitung > rtabel, dengan rtabel 0,444 maka di dapat 14 soal yang mempunyai rhitung lebih tinggi dari rtabel dan dikatakan valid dan diberikan pada Uji Reliabilitas apakah instrumen dikategorikan mempunyai reliabilitas tinggi atau tidak, dan diproleh $\mathrm{r}_{11}$ 0,918 yaitu tinggi.

Nilai post-test yang diperoleh dari kedua sampel kemudian di uji menggunakan kedua kelas. Kriteria pada kelas eksperimen yaitu dikatakan berdistribusi tabel nilai kritis signifikan didapatkan nilai adalah 0,173 dan Lhitung 0,058. 0,058<0,173 Kelas kontrol berdasarkan tabel nilai kritis Liliefors didapatkan nilai Ltabel adalah 0,173 dan Lhitung 0,038. 0,038<0,173 (tabel 1).

Data yang diperoleh nilai untuk Ltabel 1,98 maka Fhitung $<F_{\text {tabel. }}$ Dengan demikian kesimpulannya adalah kedua kelas homogen. Pengujian hipotesis dilakukan setelah Kriteria pengujian yaitu $\mathrm{H}_{0}$ di terima sedangkan Data yang diperoleh rata-rata skor kelas ekperimen $=81,92$ simpangan baku $=8,82$ varians $=77,89$ untuk kelas kontrol rata-rata skor 77,96 simpangan baku $=8,69$ dan varian 75,60 dan $\mathrm{t}$ 3,62 yang diperoleh derajat kebebasan signifikan $\alpha=0,05$ adalah 2,010.

\section{Kesimpulan}

Berdasarkan hasil penelitian disimpulkan bahwa hasil belajar siswa menggunakan Model pembelajaran Inkuiri terbimbing lebih besar dari pada Hasil belajar siswa menggunakan metode ceramah pada materi ikatan kimia. Berdasarkan pada uji- $t$ kedua nilai post-test yaitu dengan thitung 3,62 >ttabel 2,011. Ini berarti ada pengaruh yang signifikan.

\section{Daftar Pustaka}

1. Soru, E.A.; Rares, H.F.; Caroles, J. Penggunaan Three-Tier Diagnostic Test Untuk Pemetaan Tingkat Penguasaan Elektrokimia Mahasiswa Kimia Semester II. Oxygenius Journal Of Chemistry Education 2020, 2, 1-9.

2. Tamungku, R.; Tani, D.; Tuerah, J.
Analysis of Students' Misconceptions Using Two-Tier Multiple Choice Diagnostic Tests on Atomic Structure Material in Remboken State High School 1. Oxygenius Journal Of Chemistry Education 2019, 1, 66-71.

3. Ganda, B.; Lombok, J.Z.; Kumajas, J. Identifikasi struktur kognitif siswa dengan menggunakan peta konsep pada larutan asam-basa. Oxygenius Journal Of Chemistry Education 2019, 1, 20-24.

4. Sasindua, R.; Rampe, M.; Karundeng, M. Pengaruh Model Pembelajaran Anchored Instruction Terhadap Hasil Belajar Siswa. Oxygenius Journal of Chemistry Education 2020, 2, 23-28.

5. Manampiring, G.V.; Santoso, I.; Kapahang, A. Penerapan Metode POGIL Pada Materi Konsep Mol Di Kelas X IPA SMA Negeri 2 Langowan. Oxygenius Journal Of Chemistry Education 2019, 1, 72-76.

6. Hubbi, M.; Dasna, I.W.; Wonorahardjo, S. Pengaruh Strategi Pembelajaran Praktikum Sifat Koligatif Terhadapa Hasil Belajar Siswa Kelas XII. EduChemia (Jurnal Kimia dan Pendidikan) 2017, 2, 52-62, doi:10.30870/educhemia.v2i1.1211.

7. Tahulending, A.W.; Rumampuk, R.; Aloanis, A.A. Pengembangan Penuntun Praktikum Reaksi Reduksi Dan Oksidasi Berbasis Bahan Alam Dengan Menggunakan Model ADDIE. Oxygenius Journal Of Chemistry Education 2019, 1, 6165.

8. Demo, D.N.; Waworuntu, F.; Saiya, A. Studi Kelayakan LKS Praktikum Berbasis Pendekatan Saintifik Serta Dampaknya Pada Hasil Belajar Materi Sifat Larutan Penyangga. Oxygenius Journal Of Chemistry Education 2019, 1, 77-84.

9. Lumolos, G.; Gumolung, D.; Caroles, J. Studi Kelayakan Penuntun Praktikum Asam Basa Berbasis Bahan Lingkungan Menggunakan Model 3-D Dan Penerapan Metode Inkuiri Terbimbing Untuk Meningkatkan Hasil Belajar Siswa SMA Negeri 1 Tenga. Oxygenius Journal of Chemistry Education 2019, 1, 40-47.

10. Nanangkong, I.A.; Rumampuk, R.; Tani, D. Penerapan Penuntun Praktikum Dengan Menggunakan Metode Discovery 
Learning Untuk Meningkatkan Hasil Belajar Siswa Pada Materi Larutan Elektrolit Dan Nonelektrolit. Oxygenius Journal Of Chemistry Education 2019, 1, 8588.

11. Nisa, K.N.K.; Mahdian, M.; Hamid, A. Meningkatkan Keterampilan Proses Sains Dan Hasil Belajar Peserta Didik Dengan Model Pembelajaran React Pada Materi Sistem Koloid. JCAE (Journal of Chemistry And Education) 2019, 3, 40-46, doi:10.20527/jcae.v3i1.309.

12. Barthlow, M.J.; Watson, S.B. The Effectiveness of Process-Oriented Guided Inquiry Learning to Reduce Alternative Conceptions in Secondary Chemistry. School Science and Mathematics 2014, 114, 246-255,

doi:https://doi.org/10.1111/ssm.12076.

13. Schoffstall, A.M.; Gaddis, B.A. Incorporating Guided-Inquiry Learning into the Organic Chemistry Laboratory. J. Chem. Educ. 2007, 84, 848, doi:10.1021/ed084p848.

14. Smithenry, D.W. Integrating Guided Inquiry into a Traditional Chemistry Curricular Framework. International Journal of Science Education 2010, 32, 16891714, doi:10.1080/09500690903150617.

15. Lewis, S.E.; Lewis, J.E. Seeking Effectiveness and Equity in a Large College Chemistry Course: An HLM Investigation of Peer-Led Guided Inquiry. Journal of Research in Science Teaching 2008, 45 , 794-811, doi:https://doi.org/10.1002/tea.20254.

16. Ural, E. The Effect of Guided-Inquiry Laboratory Experiments on Science Education Students' Chemistry Laboratory Attitudes, Anxiety and Achievement. Journal of Education and Training Studies 2016, 4 ,

217-227, doi:10.11114/jets.v4i4.1395.

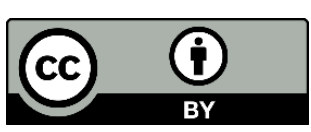

(C) 2020 by the authors. Licensee Oxygenius Journal Of Chemistry Education. This article is an open access article distributed under the terms and conditions of the Creative Commons Attribution (CC BY) license (http://creativecommons.org/licenses/by/4.0/). 